\title{
Heterologous expression of cyclodextrin glycosyltransferase from Paenibacillus macerans in Escherichia coli and its application in 2-O-a-D-glucopyranosyl-L- ascorbic acid production
}

Yujia Jiang ${ }^{1}$, Jie Zhou ${ }^{1,2}$, Ruofan Wu' , Fengxue Xin ${ }^{1,2}$, Wenming Zhang ${ }^{2}$, Yan Fang ${ }^{1,2}$, Jiangfeng Ma ${ }^{1,2}$, Weiliang Dong ${ }^{1,2^{*}}$ and Min Jiang ${ }^{1,2^{*}}$

\begin{abstract}
Background: Cyclodextrin glucanotransferase (CGTase) can transform L-ascorbic acid (L-AA, vitamin C) to 2-O-a-Dglucopyranosyl-L-ascorbic acid (AA-2G), which shows diverse applications in food, cosmetic and pharmaceutical industries.

Results: In this study, the cgt gene encoding a-CGTase from Paenibacillus macerans was codon-optimized (opt-cgt) and cloned into pET-28a (+) for intracellular expression in E. coli BL21 (DE3). The Opt-CGT was purified by Ni ${ }^{2+}-$ NTA resin with a 55\% recovery, and specific activity was increased significantly from 1.17 to $190.75 \mathrm{U} \cdot \mathrm{mg}^{-1}$. In addition, the enzyme was adopted to transform L-AA into $9.1 \mathrm{~g} / \mathrm{L}$ of AA-2G. Finally, more economic substrates, including $\beta$-cyclodextrin, soluble starch, corn starch and cassava starch could also be used as glycosyl donors, and 4.9, 3.5, 1.3 and $1.5 \mathrm{~g} / \mathrm{L}$ of AA-2G were obtained, respectively.

Conclusions: N-terminal amino acid is critical to the activity of CGTase suggested by its truncation study. Furthermore, when the Opt-CGT was flanked by $\mathrm{His}_{6}$-tags on the $\mathrm{C}$ - and $\mathrm{N}$-terminal, the recovery of purification by $\mathrm{Ni}^{2+}$-NTA resin is appreciably enhanced. a-cyclodextrin was the ideal glycosyl donor for AA-2G production. In addition, the selection of low cost glycosyl donors would make the process of AA-2G production more economically competitive.
\end{abstract}

Keywords: Cyclodextrin glucanotransferase, Optimized codons, Glycosyl donors, 2-O-a-D-glucopyranosyl-L-ascorbic acid

\section{Background}

Ascorbic acid (Vitamin C, L-AA, Vc) is an essential vitamin in maintaining the health of body, which could not be synthesized naturally [1]. However, its hydroxyl group in the position of $\mathrm{C}-2$ is extremely instable, especially in oxidative, lighted and hot environment, so the application of L-AA is subjected to a lot of restrictions [2]. 2 -O- $\alpha$-D-glucopyranosyl-L-ascorbic acid (AA-2G) is a

\footnotetext{
* Correspondence: dwl@njtech.edu.cn; bioengine@njtech.edu.cn ${ }^{1}$ State Key Laboratory of Materials-Oriented Chemical Engineering, College of Biotechnology and Pharmaceutical Engineering, Nanjing Tech University, Puzhu South Road 30\#, Nanjing 211800, People's Republic of China Full list of author information is available at the end of the article
}

type of glucosylated L-AA, which is widely used in cosmetic, health products or other fields. In addition, it can play the role in whitening the skin owing to the L-AA released by $\alpha$-glucosidase from AA-2G. Five kinds of enzymes could catalyze the AA-2G production, including $\alpha$-amylase, $\alpha$-glucosidase, sucrose phosphatase, $\alpha$-isomaltosyl glucosaccharide-forming enzyme and cyclodextrin glycosyltransferase (EC 2.4.1.19, CGTase). Among them, CGTase with higher substrate specificity, higher production and more excellent thermal stability was considered to be the best enzyme for industrial production of AA-2G [3-6].

(c) The Author(s). 2018 Open Access This article is distributed under the terms of the Creative Commons Attribution 4.0 International License (http://creativecommons.org/licenses/by/4.0/), which permits unrestricted use, distribution, and 
CGTase is an industrially important enzyme for $\alpha-, \beta-$ or $\gamma$-cyclodextrins (CDs) production, which are extensively used in agriculture, chemicals, cosmetics, foods and pharmaceuticals [7]. Actually, CGTase has been discovered in a great number of Bacillus, Thermoanaerobacter, Brevibacterium and Thermoanaerobacterium [810]. The CGTase from Bacillus genus belonging to glycoside hydrolases family 13 (GH13) is the most commonly used one, which can catalyze three kinds of reactions: cyclization, intramolecular transglycosylation and low hydrolytic reaction [11-13]. In addition, intramolecular transglycosylation reaction includes disproportionation reaction (transfer the donor substrate to acceptor substrate) and coupling reaction (cleave cyclodextrins and transfer the resulting maltooligosaccharide to acceptor substrate) [11].

The productivities of CGTases from wild strains are relatively low, partly resulting in high production costs for industrial applications. Currently, $\alpha$-CGTases were mainly obtained by extracellular heterologous expression in E. coli or B. subtills. Compared with extracellular expression, intracellular expression would simplify the preservation, facilitate enzyme enrichment and isolate the disturbance of the external circumstances. In addition, typical yield of purified $\alpha$-CG Tas was at a relatively low level by one-step affinity chromatography on $\mathrm{Ni}^{2+}$-NTA resin, and $>95 \%$ of the recombinant enzyme was left in the flow-through fraction because of the C-terminal $\mathrm{His}_{6}$-tag was partially inaccessible [14].

Previous reports showed that abundant biologically inactive inclusion bodies of $\alpha$-CGTases accumulated when it was expressed intracellularly $[14,15]$. Codon optimization is known to be an important strategy which could improve the levels of gene soluble expression in the host and ultimately affects enzyme production [16]. To enhance the $\alpha$-CGTase soluble expression, the $\alpha$-CGTase encoding gene from Paenibacillus macerans JFB05-01 was codon-optimized first, and then expressed in E. coli BL21(DE3) intracellularly. The recombinant Opt-CGT was flanked by $\mathrm{His}_{6}$-tags on the $\mathrm{C}$ - and $\mathrm{N}$-terminal to increase binding affinity with $\mathrm{Ni}^{2+}$-NTA resin. The enzymatic properties were characterized and its ability of transforming L-AA to AA-2G was investigated. In addition, other more economic glycosyl donors were selected in order to decrease the cost of AA-2G production.

\section{Methods}

\section{Chemicals and media}

Peptone and yeast extract were purchased from Oxoid Co. Ltd. (Beijing, China), soluble starch was produced by Xilong chemical Co. Ltd. (Guangzhou, China), $\alpha$-cyclodextrin was purchased from Sangon Biotech. Co. Ltd. (Shanghai, China) and the other chemical reagents were purchased from Lingfeng chemical reagents Co. Ltd. (Shanghai, China). All molecular biology reagents were purchased from TaKaRa Co., Ltd. (Dalian, China). All chemicals used in this study were of analytical grade or a higher purity. The Luria-Bertani (LB) medium was used to culture the E. coli strains in this study. The improved terrific broth (ITB) medium containing $15 \mathrm{~g} / \mathrm{L}$ maltose, $12 \mathrm{~g} / \mathrm{L}$ peptone, $24 \mathrm{~g} / \mathrm{L}$ yeast extract, $16.43 \mathrm{~g} / \mathrm{L} \quad \mathrm{K}_{2} \mathrm{HPO}_{4} \cdot 3 \mathrm{H}_{2} \mathrm{O}$ and

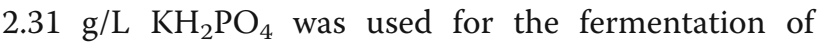
recombinant strain.

\section{Strain, plasmid and primers}

Secondary structure in dot-bracket notation with a minimum free energy (MFE) could be predicted using the ViennaRNA Web Services (http://rna.tbi.univie.ac.at/) [17]. Codon adaptation index (CAI) based on the set of highly expressed genes from $E$. coli was calculated using the CAIcal server (http://genomes.urv.es/CAIcal/) [18]. The mRNA senior structure and possible RNA stem structure were predicted by a web site of http://www.genebee.msu.su/services/rna2_reduced.html. Finally, the $\alpha$-CGTase encoding gene (cgt) from $P$. macerans JFB0501 was codon-optimized by GeneWiz, Inc. (Suzhou, China) and the resulting gene was named as opt-cgt. The expression vector pET28a (+) with two $\mathrm{His}_{6}$-tags at both of $\mathrm{C}$-terminal and $\mathrm{N}$-terminal was used. The $E$. coli BL21 (DE3) was used as host strain and routinely grown aerobically at $37{ }^{\circ} \mathrm{C}$ in LB broth or on LB agar. All the primers used in the study were listed in Table 1.

\section{Cloning and expression of the opt-cgt gene encoding a-CGTase}

The opt-cgt gene without signal peptide was amplified using the primers F1/R1 listed in Table 1 using PrimeSTAR HS DNA polymerase. Then, the PCR products were inserted into the $B a m \mathrm{H}$ I and Xho I sites of the DNA pET28a (+) plasmid to produce the pET-opt-cgt plasmid by One Step Cloning Kit (Vazyme Biotech. Co., Ltd., Nanjing, China). The recombinant plasmid was transformed into $E$. coli BL21 (DE3) and designated as $E$. coli BL21 (DE3-pET-opt-cgt). Finally, the insertion of the genes was confirmed by DNA sequencing (GenScript Biotech. Co, Ltd., Nanjing, China).

E. coli BL21 (DE3-pET-opt-cgt) was incubated in $5 \mathrm{~mL}$ of LB medium supplemented with $30 \mu \mathrm{g} / \mathrm{mL}$ of kanamycin at $37^{\circ} \mathrm{C}$ for $12 \mathrm{~h}$ as the inoculum. The $1.0 \mathrm{~mL}$ inoculum was inoculated into a $500 \mathrm{~mL}$ Erlenmeyer flask containing $100 \mathrm{~mL}$ ITB medium with $30 \mu \mathrm{g} / \mathrm{mL}$ kanamycin and then the condition was maintain at $200 \mathrm{r} \cdot \mathrm{min}^{-1}$ and $37^{\circ} \mathrm{C}$ until the optical density at $600 \mathrm{~nm}\left(\mathrm{OD}_{600}\right)$ reached 0.5 to 0.6. Then, protein expression was induced with $0.01 \mathrm{mM}$ IPTG and the culture temperature was lowered to $18{ }^{\circ} \mathrm{C}$ for $20 \mathrm{~h}$. The bacterial cells were harvested by centrifugation (Eppendorf Centrifuge 5810 R, F-34-6-38 rotor, Brinkman Instruments Inc., USA) at $8085 \times \mathrm{g}$ and $4{ }^{\circ} \mathrm{C}$ for $10 \mathrm{~min}$, 
Table 1 Oligonucleotide primers used for PCR

\begin{tabular}{|c|c|}
\hline Primers & Oligonucleotide sequences ( $5^{\prime}$ to $3^{\prime}$ ) \\
\hline F1 & 5'-CAGCAAATGGGTCGCGGATCCAGTCCTGACACCAGCGTGG-3' \\
\hline R1 & 5'-GGTGGTGGTGGTGGTGCTCGAGATTCTGCCAGTCAACGGTCACTG-3' \\
\hline F2 & 5'-CAGCAAATGGGTCGCGGATCCCCTGACACCAGCGTGGATAACAAGG-3' \\
\hline R2 & 5'-GGTGGTGGTGGTGGTGCTCGAGATTCTGCCAGTCAACGGTCACTGTA-3' \\
\hline F3 & 5'-CAGCAAATGGGTCGCGGATCCAGCGTGGATAACAAGGTGAACTTTAGT-3' \\
\hline R3 & 5'-GGTGGTGGTGGTGGTGCTCGAGATTCTGCCAGTCAACGGTCA-3' \\
\hline F4 & 5'-CAGCAAATGGGTCGCGGATCCGATAACAAGGTGAACTITAGTACAGAT-3' \\
\hline R4 & 5'-GTGGTGGTGGTGGTGCTCGAGATTCTGCCAGTCAACGGT-3' \\
\hline F5 & 5'-CAGCAAATGGGTCGCGGATCCGTGAACTTTAGTACAGATGTTATTT-3' \\
\hline R5 & 5'-GTGGTGGTGGTGGTGCTCGAGATTCTGCCAGTCAACGGT-3' \\
\hline
\end{tabular}

Underlined segments represent restriction enzyme cutting sites

washed twice with $50 \mathrm{mM}$ PBS (pH 6.0). The E. coli BL21 (DE3-pET-opt-cot) cells were disrupted by a scientz-II D ultrasonic generator (Ningbo Scientz Biotech. co., Ltd., Ningbo, China) in the ice bath for $10 \mathrm{~min}$. The cell debris was removed by centrifugation at $8085 \times \mathrm{g}$ and $4{ }^{\circ} \mathrm{C}$ for 20 min.

In addition, the effects of Opt-CGT N-terminal amino acids on enzymatic activity were carried out by truncating expression. Four PCR fragments (cut off one amino acid, four amino acids, six amino acids and nine amino acids) were amplified using the primers F2/R2, F3/R3, F4/R4 and F5/R5, respectively (Table 1 ). Then, the four PCR fragments were inserted into pET28a $(+)$ vector to produce the pET-cgt-t1AA, pET-cgt-t4AA, pET-cgt-t6AA and pET-cgt-t9AA plasmids which were transformed into E. coli BL21 (DE3) as described above.

\section{Purification and SDS-PAGE}

The recombinant Opt-CGT with $\mathrm{His}_{6}$-tags was purified with $\mathrm{Ni}^{2+}$-NTA resin (Qiagen, Valencia, CA, USA) [19]. After washing of non-target proteins with $25 \mathrm{mM}$ imidazole in $50 \mathrm{mM} \mathrm{PBS} \mathrm{(pH} \mathrm{7.0),} \mathrm{the} \mathrm{target} \mathrm{fusion} \mathrm{protein} \mathrm{was}$ eluted with a linear concentration gradient of imidazole in $50 \mathrm{mM}$ PBS ( $\mathrm{pH}$ 7.0). The fractions containing target protein were collected and dialyzed against $50 \mathrm{mM}$ PBS (pH 7.0) overnight at $4{ }^{\circ} \mathrm{C}$ to remove imidazole. The purified Opt-CGT and truncated proteins were diluted with buffer solution to $100 \mathrm{~mL}$ and stored at $4{ }^{\circ} \mathrm{C}$, respectively.

The proteins were electrophoresed by sodium dodecyl sulfatepolyacrylamide gel electrophoresis (SDS-PAGE) and visualized by staining with Coomassie Brilliant Blue R-250 [20, 21]. SDS-PAGE was performed on a $12 \%$ gel using electrophoresis apparatus at $80 \mathrm{~V}$ for the first $60 \mathrm{~min}$, followed by $120 \mathrm{~V}$ for $2 \mathrm{~h}$.

\section{Assay for cyclization activity of a-CGTase}

$\alpha$-Cyclodextrin activity was determined using the methyl orange method during starch hydrolysis [6]. The $0.1 \mathrm{~mL}$ of Opt-CGT was incubated in $0.9 \mathrm{~mL}$ of $50 \mathrm{mM}$ PBS $\left(\mathrm{pH}\right.$ 6.0) containing $3 \%(w / v)$ soluble starch at $40{ }^{\circ} \mathrm{C}$ for $10 \mathrm{~min}$. Then, $1.0 \mathrm{~mL}$ of $1 \mathrm{M} \mathrm{HCl}$ was added to terminate the reaction and provided an acidic environment, and $1.0 \mathrm{~mL}$ of $0.1 \mathrm{mM}$ methyl orange in $50 \mathrm{mM}$ PBS (pH 6.0) was also added. Then the reaction mixture was incubated at $16{ }^{\circ} \mathrm{C}$ for $20 \mathrm{~min}$ and the amount of $\alpha$-cyclodextrin in the mixture was spectrophotometrically determined by measuring the absorbance at $505 \mathrm{~nm}$. The standard curve was calculated according to the $\mathrm{OD}_{505}$ of different concentration of pure AA-2G. One unit of $\alpha$-cyclodextrin-forming activity was defined as the amount of enzyme that was able to produce $1 \mu \mathrm{mol}$ of $\alpha$-cyclodextrin per min.

\section{Biochemical properties of the purified Opt-CGT Effects of temperature and $\mathrm{pH}$ on Opt-CGT activity and stability}

The optimal reaction $\mathrm{pH}$ was assessed at $40{ }^{\circ} \mathrm{C}$ using the following buffers: $50 \mathrm{mM}$ citrate buffer, $\mathrm{pH}$ 4.0-6.0; $50 \mathrm{mM}$ PBS, pH 6.0-8.0; $50 \mathrm{mM}$ glycine- $\mathrm{NaOH}$ buffer, $\mathrm{pH}$ 8.0-10.0. The effect of temperature on Opt-CGT activity was determined under the optimal $\mathrm{pH}$ at different temperatures ranging from 16 to $80{ }^{\circ} \mathrm{C}$. To measure $\mathrm{pH}$ stability, the enzyme was incubated at $4{ }^{\circ} \mathrm{C}$ for $1 \mathrm{~h}$ in different buffers and the residual activity was determined. The thermal stability of Opt-CGT was assessed by incubating the enzyme preparations at different temperatures for a certain time until the remaining activity decreased below $50 \%$ of its initial cyclization activity. Non-heated enzyme was used as the control (100\%).

\section{Effects of metal ions and chemical agents on Opt-CGT activity}

Purified Opt-CGT was treated with $1 \mathrm{mM}$ EDTA for $5 \mathrm{~h}$ at $4{ }^{\circ} \mathrm{C}$ and then dialyzed against $50 \mathrm{mM}$ PBS (pH 6.0) to remove the EDTA. For reactivation, the metal-free enzyme was incubated with divalent metal ions $\left(\mathrm{Fe}^{2+}, \mathrm{Ba}^{2+}, \mathrm{Cu}^{2+}\right.$, $\mathrm{Co}^{2+}, \mathrm{Ni}^{2+}, \mathrm{Zn}^{2+}, \mathrm{Ca}^{2+}, \mathrm{Mg}^{2+}$ and $\mathrm{Mn}^{2+}$ ) at a final 
concentration of $1 \mathrm{mM}$ for $10 \mathrm{~min}$, followed by the remaining activity determination. The procedure used to assess the metal ions was also used to determine the effects of chemical agents (Triton X-100, SDS, Tween20, Tween80 and urea) and organic reagents (methanol, ethanol, acetonitrile, isopropanol and DMSO) [22, 23]. The activity in the absence of any additives was used as the control (100\%).

\section{Assay for AA-2G synthesis}

The original reaction mixture in $50 \mathrm{mM}$ PBS (pH 5.0) contained $100 \mathrm{~g} / \mathrm{L}$ of L-AA, $100 \mathrm{~g} / \mathrm{L}$ of $\alpha$-cyclodextrin and $60 \mathrm{U}$ of Opt-CGT. The reaction mixture was incubated at $40{ }^{\circ} \mathrm{C}$ for $24 \mathrm{~h}$ in the dark and filled with nitrogen. In order to hydrolyze the AA-2-oligosaccharides (AA-2Gs) to AA-2G, the glucoamylase was added to the mixture at a final concentration of $10 \mathrm{U} / \mathrm{mL}$. The reaction mixture was incubated at $55{ }^{\circ} \mathrm{C}$ for another $24 \mathrm{~h}$. What's more, the glycosyl donors were also optimized, and $\alpha$-cyclodextrin, $\beta$-cyclodextrin, soluble starch, corn starch and cassava starch were all used as the glycosyl donors.

A separation column (internal diameter, $4.6 \mathrm{~mm}$; length, $250 \mathrm{~mm}$ ) filled with Kromasil $100-5-\mathrm{C}_{18}$ was used for AA-2G HPLC analysis. The mobile phase was $25 \mathrm{mM}$ $\mathrm{KH}_{2} \mathrm{PO}_{4}$ : methanol $(99.5: 0.5, \mathrm{vol} / \mathrm{vol})$ and adjusted $\mathrm{pH}$ to 2.0 using $\mathrm{H}_{3} \mathrm{PO}_{4}$. The flow rate was $0.8 \mathrm{~mL} / \mathrm{min}$ and temperature of column was $25{ }^{\circ} \mathrm{C}$. The detection wavelength was $238 \mathrm{~nm}$. The retention time of the pure AA-2G was $13.034 \mathrm{~min}$, and the amount of AA-2G was calculated on the basis of the peak area.

\section{Results and discussion}

\section{Cloning and expression of the opt-cgt gene}

The Opt-CGT was successfully expressed in E. coli BL21 (DE3) according to the results of SDS-PAGE and the

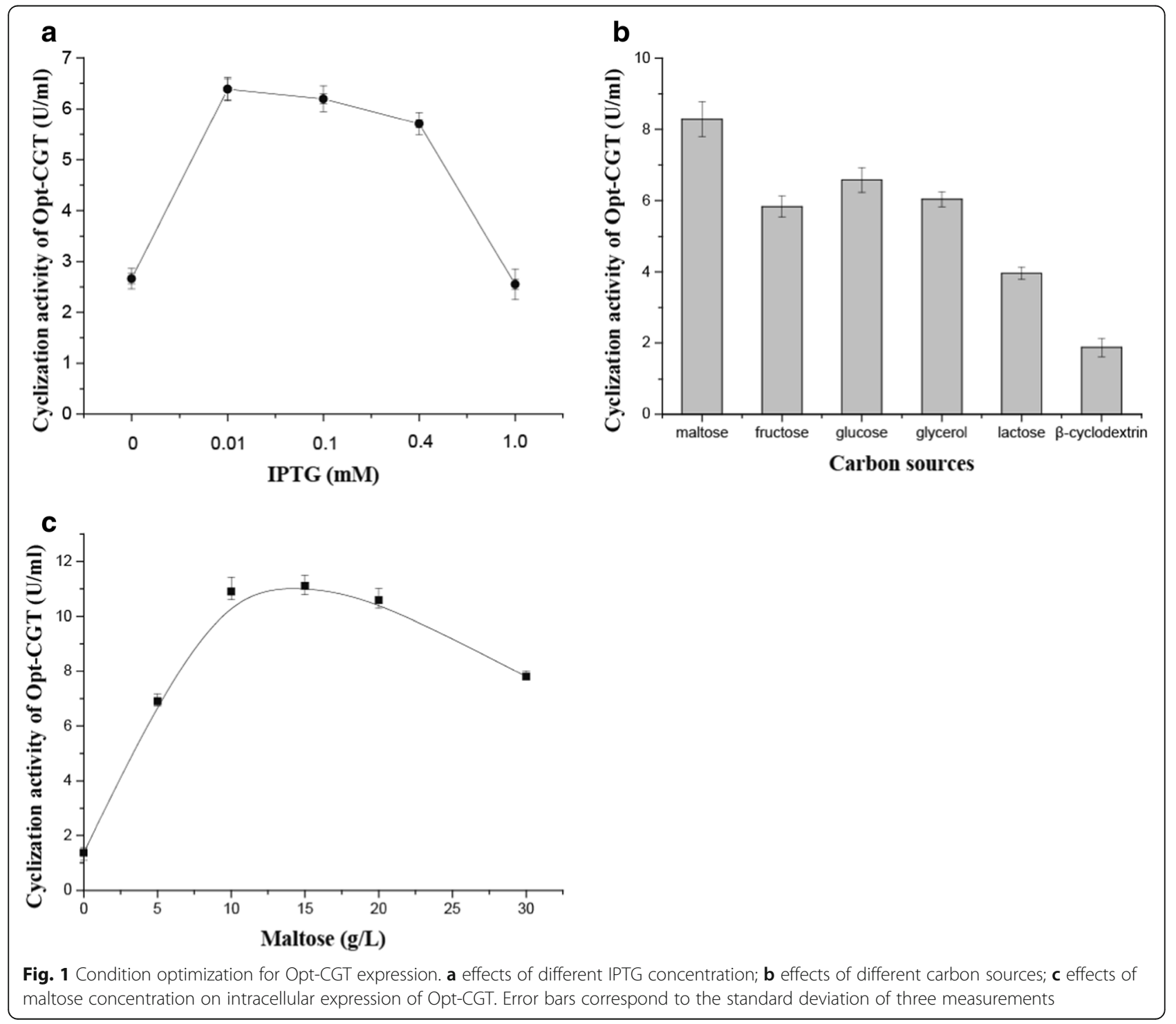


analysis of activity. The activity of CGTase reached $6.25 \mathrm{U} / \mathrm{mL}$ after IPTG-induced $20 \mathrm{~h}$. Generally, $P$. macerans should be incubated at $37{ }^{\circ} \mathrm{C}$ for $72 \mathrm{~h}$ to obtain the CGTase [24]. Hence, the fermentation time was shortened significantly by intracellular heterologous expression in E. coli comparing to that for P. macerans. In addition, the cgt gene was also cloned into pET-20b (+) and extracellularly expressed in E. coli with a higher enzyme activity of $22.5 \mathrm{U} / \mathrm{mL}$ and longer fermentation time of $90 \mathrm{~h}$ [14].

Codon bias was considered as the most important determinant of translation efficiency, expression level and the folding energy of mRNA [25]. The value of CAI increased from 0.74 to 0.86 for $E$. coli after the optimization of $c g t$ gene. In theory, the CAI of 1.0 is considered as ideal, while a CAI of more than 0.8 is rated as good for expression in the desired expression organism [26]. The minimum free energy $(\Delta G)$ of the optimal secondary structure in dot-bracket notation was $-770.9 \mathrm{kcal} \cdot \mathrm{mol}^{-1}$ ( $1 \mathrm{cal}=4.2 \mathrm{~J}$ ), while the $\Delta G$ of non-optimized codons was $-774.10 \mathrm{kcal} \cdot \mathrm{mol}^{-1}$ by ViennaRNA Web Services. Yin et al. reported that $\Delta G$ is closely related to translation efficiency and increasing $\Delta G$ can enhance the expression level [27]. Amaral et al. demonstrated that the folding free energy of the $5^{\prime}$ end of mRNA transcripts could have significant effects on translation efficiency and overall protein abundance [18]. Otherwise, the number of stable stem regions which has lower energy under $-15 \mathrm{kcal} \cdot \mathrm{mol}^{-1}$ was decreased from 15 to 10 after codon optimization. The lower energy was advantageous to soluble heterologous expression in E. coli [28].

\section{Optimization of expression conditions and purification of Opt-CGT}

In order to improve the enzyme activity of Opt-CGT, expression conditions were further optimized, including IPTG concentration and carbon sources. The optimized conditions for Opt-CGT expression was $200 \mathrm{r} \cdot \mathrm{min}^{-1}$ and $18{ }^{\circ} \mathrm{C}$ for $20 \mathrm{~h}$ with $0.01 \mathrm{mM}$ of IPTG. The highest cyclization activity of Opt-CGT reached $11.12 \mathrm{U} / \mathrm{mL}$ when $15 \mathrm{~g} / \mathrm{L}$ of maltose was used as the carbon source (Fig. $1 \mathrm{a}, \mathrm{b}$ and c). In general, intracellular expression of $\alpha$-CGTase is more beneficial to the collection of enzyme. However, the enzyme activity is lower than that of extracellular expression. For example, $\alpha$-cgt was cloned into pET-20b (+) and expressed in E. coli with the extracellular enzyme activity of $55.3 \mathrm{U} / \mathrm{mL}$ [29].

The recombinant Opt-CGT was eluted by $\mathrm{Ni}^{2+}$-NTA resin and purified recombinant Opt-CGT was analyzed using SDS-PAGE (12\%). The purified enzyme gave a single band on SDS-PAGE (Fig. 2). The molecular mass of the denatured enzyme was approximately $74 \mathrm{kDa}$, which was in good agreement with the theoretical molecular mass. After the $\mathrm{Ni}^{2+}$-NTA resin purification process, Opt-CGT was purified 163 -fold with a $55 \%$ recovery and specific activity was increased significantly from 1.17 to $190.75 \mathrm{U} \cdot \mathrm{mg}^{-1}$. This is a similar specific activity with the reported two-step purification scheme (Q-sepharose and phenyl-superose), which the specific activity of purified recombinant $\alpha$-CGTase was $198.82 \mathrm{U} \cdot \mathrm{mg}^{-1}$ [14] (Table 2). However, the recovery yield of purified enzyme reported by $\mathrm{Li}$ et al. was less than $5 \%$ by one-step affinity chromatography on $\mathrm{Ni}^{2+}{ }_{-} \mathrm{NTA}$ resin, which is a relatively low level. The

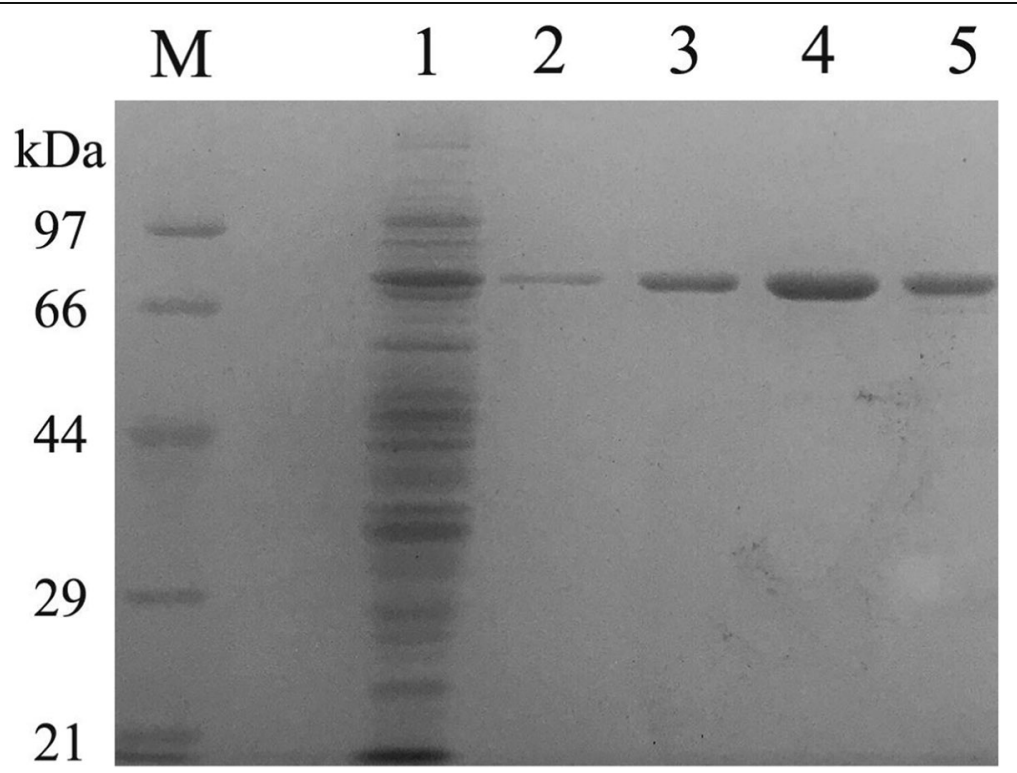

Fig. 2 SDS-PAGE analysis of the purified recombinant Opt-CGT. M protein marker; Lane 1 unpurified total soluble proteins from induced BL21 (DE3) harboring pET-opt-cgt; Lane 2-5 soluble proteins purified by nickel affinity chromatography from induced BL21 (DE3) harboring pET-opt-cgt $(15 \mu \mathrm{L})$ 
Table 2 Comparison of purification process between native CGTase and Opt-CGT

\begin{tabular}{lll}
\hline Details & Opt-CGT (This study) & Native CGTase \\
\hline Origin Organism & Paenibacillus macerans JFB05-01 & Paenibacillus macerans JFB05-01 \\
Codon optimization & Yes & No \\
CAI (E. coli) & 0.86 & 0.74 \\
Plasmid/host & pET-28a (+)/E. coli BL21 & pET-20b (+)/E. coli BL21 \\
Induction time (h) & 20 & 90 \\
Total protein of crude enzyme (mg) & 330 & 401 \\
Purification methods & $\mathrm{Ni}^{2+}$-NTA & Q-Sepharose + Phenyl-Superose \\
Total protein of purified enzyme (mg) & 7.66 & 8.31 \\
Specific activity (U/mg) & 190.75 & 198.82 \\
Purification fold & 163 & 13.17 \\
Yield $(\%)$ & 55 & 27.27
\end{tabular}
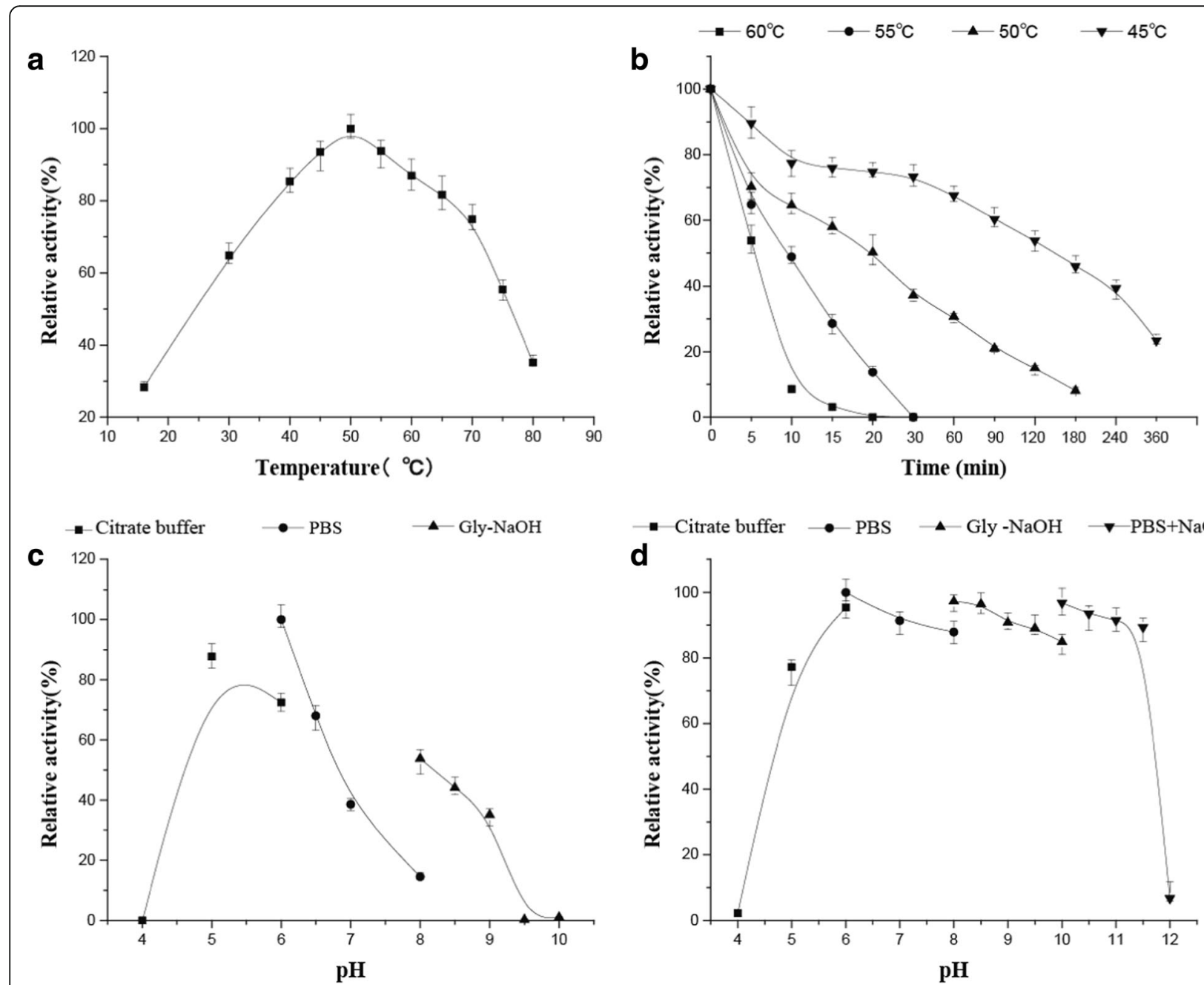

Fig. 3 Effects of temperature and pH on enzyme activity and stability of the Opt-CGT. a determination of the optimum temperature; $\mathbf{b}$ thermal stability; $\mathbf{c}$ determination of the optimum $\mathrm{pH} ; \mathbf{d}$ pH stability. Error bars correspond to the standard deviation of three measurements 
Table 3 Effects of bivalent metal ions and chemical agents on Opt-CGT activity

\begin{tabular}{|c|c|c|}
\hline Additives & Concentration & Relative activity (\%) \\
\hline \multicolumn{3}{|l|}{ Metal ions } \\
\hline No addition & & $100 \pm 1.8$ \\
\hline $\mathrm{Fe}^{2+}\left(\mathrm{FeCl}_{2}\right)$ & $1 \mathrm{mM}$ & $80.6 \pm 3.5$ \\
\hline $\mathrm{Mg}^{2+}\left(\mathrm{MgCl}_{2}\right)$ & $1 \mathrm{mM}$ & $96.6 \pm 1.9$ \\
\hline $\mathrm{Cu}^{2+}\left(\mathrm{CuCl}_{2}\right)$ & $1 \mathrm{mM}$ & $59.9 \pm 4.8$ \\
\hline $\mathrm{Ca}^{2+}\left(\mathrm{CaCl}_{2}\right)$ & $1 \mathrm{mM}$ & $114.9 \pm 2.4$ \\
\hline $\mathrm{Ni}^{2+}\left(\mathrm{NiCl}_{2}\right)$ & $1 \mathrm{mM}$ & $79.3 \pm 3.9$ \\
\hline $\mathrm{Zn}^{2+}\left(\mathrm{ZnCl}_{2}\right)$ & $1 \mathrm{mM}$ & $97.3 \pm 2.7$ \\
\hline $\mathrm{Ba}^{2+}\left(\mathrm{BaCl}_{2}\right)$ & $1 \mathrm{mM}$ & $111.7 \pm 2.2$ \\
\hline $\mathrm{Mn}^{2+}\left(\mathrm{MnCl}_{2}\right)$ & $1 \mathrm{mM}$ & $101.8 \pm 3.1$ \\
\hline $\mathrm{Co}^{2+}\left(\mathrm{CoCl}_{2}\right)$ & $1 \mathrm{mM}$ & $94.1 \pm 2.3$ \\
\hline EDTA & $1 \mathrm{mM}$ & $92.5 \pm 2.8$ \\
\hline \multicolumn{3}{|l|}{ Organic solvents } \\
\hline Methanol & $10 \%$ & $36.9 \pm 3.2$ \\
\hline Ethanol & $10 \%$ & $13.8 \pm 1.2$ \\
\hline Acetonitrile & $10 \%$ & $5.5 \pm 0.9$ \\
\hline Isopropanol & $10 \%$ & $18.9 \pm 2.8$ \\
\hline DMSO & $5 \%$ & $74.2 \pm 2.3$ \\
\hline \multicolumn{3}{|l|}{ Surfactants } \\
\hline Tween-20 & $20 \mathrm{mg} \cdot \mathrm{mL}^{-1}$ & $32.4 \pm 3.1$ \\
\hline Tween-80 & $20 \mathrm{mg} \cdot \mathrm{mL}^{-1}$ & $55.8 \pm 3.7$ \\
\hline Triton X-100 & $20 \mathrm{mg} \cdot \mathrm{mL}^{-1}$ & $87.1 \pm 2.4$ \\
\hline SDS & $2 \mathrm{mg} \cdot \mathrm{mL}^{-1}$ & $36.9 \pm 3.1$ \\
\hline \multicolumn{3}{|c|}{ Enzyme inhibitors } \\
\hline Urea & $20 \mathrm{mg} \cdot \mathrm{mL}^{-1}$ & $97.6 \pm 2.7$ \\
\hline
\end{tabular}

increased yield of purified enzyme maybe because the plasmid of pET28a (+) flanked by $\mathrm{His}_{6}$-tags on the Cand N-terminal, which could increase Opt-CGT binding affinity with $\mathrm{Ni}^{2+}$-NTA resin.

\section{Effects of $\mathrm{N}$-terminal amino acid on cyclization activity of Opt-CGT}

The $\mathrm{NH}_{2}$ domain of CGTase was considered more important for cyclization [8]. In this study, 1 amino acid, 4 amino acids, 6 amino acids and 9 amino acids were truncated in the N-terminal of Opt-CGT, respectively. These truncated Opt-CGTs were designated CGT-t1AA, CGT-t4AA, CGT-t6AA and CGT-t9AA, which were expressed in E. coli BL21 (DE3), respectively. SDS-PAGE results indicated that all samples were highly expressed in E. coli (data not shown). However, the cyclization activity of CGT-t1AA was almost unchanged, and the activity of CGT-t4AA and CGT-t6AA was significantly reduced, whereas no activity could be detected by truncating 9 amino acids of Opt-CGT.

Salt bridges were important for the structure and function of enzymes, such as in the model metalloprotease PAE [30]. Based on the crystal structure of CGTase, two important salt bridges were found in the first 9 amino acids of CGTase at N-terminal, including Asp3-Arg521 and Lys9-Asp224. Three conserved amino acids (Asp229, Glu258 and Asp329) constituted the catalytic residues, which are important for cyclization activity of $\alpha$-CGTase [31, 32]. Asp224 is closed to the Asp229 which is the active center of $\alpha$-CGTase, thus, the destruction of the salt bridge Lys9-Asp224 may be the main reason to make Opt-CGT inactivation. The fact that the activity of CGT-t4AA and CGT-t6AA decreased but not completely lost maybe because Arg521 is relatively far from activity center of $\alpha$-CGTase. This result could suggest the necessity of the N-terminal amino acids for Opt-CGT.

\section{Biochemical properties of purified opt-CGT Effects of temperature on opt-CGT activity and stability}

In this study, the optimum temperature of the recombinant Opt-CGT was $50{ }^{\circ} \mathrm{C}$ for the cyclization activity (Fig. 3a). The recombinant enzyme exhibited more than $80 \%$ of maximum cyclization activity between $40{ }^{\circ} \mathrm{C}$ and $65^{\circ} \mathrm{C}$ (Fig. 3a). Opt-CGT was stable and retained $>80 \%$ residual activity for $30 \mathrm{~min}$ at temperatures $<45{ }^{\circ} \mathrm{C}$, but was unstable at temperatures $>50{ }^{\circ} \mathrm{C}$ (Fig. 3b). These results indicated that Opt-CGT was a mesophilic enzyme.

\section{Effects of $\mathrm{pH}$ on Opt-CGT activity and stability}

Opt-CGT exerted high levels of activity at pH 5.0-6.5 with an optimum pH of 6.0 (Fig. 3c). Almost no activity was detected at $\mathrm{pH}$ below 4.0 or above 9.5 . The recombinant Opt-CGT was more active in glycine- $\mathrm{NaOH}$ buffer compared with that in PBS buffer at the same $\mathrm{pH}$. The stabilities of recombinant Opt-CGT for the

Table 4 Comparison of the properties between native CGTase and Opt-CGT

\begin{tabular}{lll}
\hline Details & Opt-CGT (This study) & Native CGTase \\
\hline Induction time $(\mathrm{h})$ & 20 & 70 \\
Molecular mass & $74 \mathrm{kDa}$ & $75 \mathrm{kDa}$ \\
Optimum temperature $\left({ }^{\circ} \mathrm{C}\right)$ & 50 & 50 \\
Half-life time of the CGTases at $50{ }^{\circ} \mathrm{C}(\mathrm{min})$ & $\sim 20$ & $\sim 48$ \\
Optimum pH & 6.0 & 5.5 \\
pH stabilities (The activity of CGTases retained $>80 \%)$ & $6.0-11.5$ & $6.0-10.0$ \\
\hline
\end{tabular}



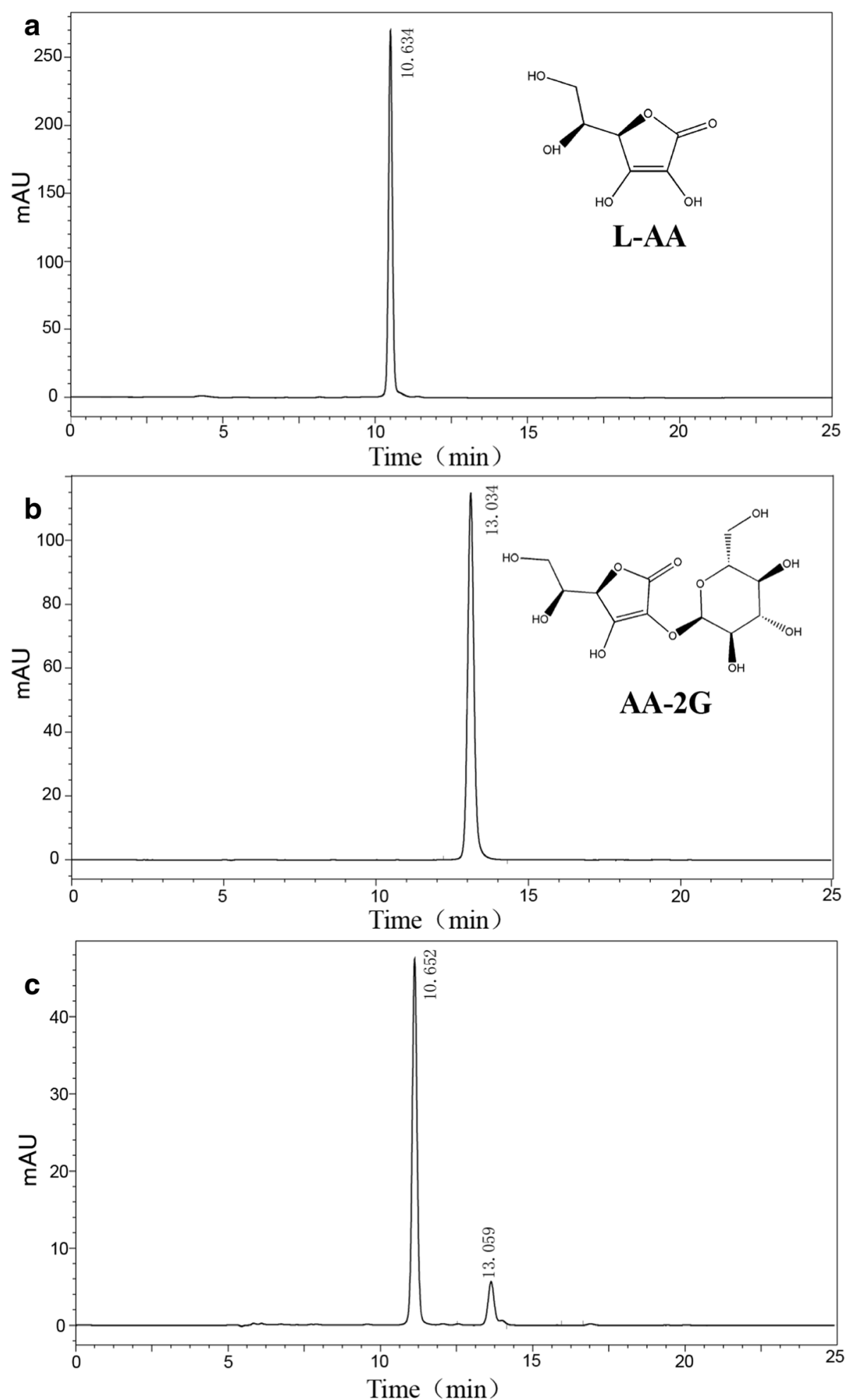

Fig. $4 \mathrm{HPLC}$ analysis of AA-2G production by the Opt-CGT. a the standard sample of L-AA $(0.1 \mathrm{~g} / \mathrm{L})$; b the standard sample of AA-2G $(0.1 \mathrm{~g} / \mathrm{L})$; c reaction products obtained: The peak I is the rest of L-AA and the peak II is the generated AA-2G. The reaction sample was diluted 1000 times before analysis 
cyclization activity was also examined in the $\mathrm{pH}$ range of 4.0-12.0 (Fig. 3d). Opt-CGT retained $>70 \%$ of its activity after storing at $\mathrm{pH} 5.0-11.5$ for $1 \mathrm{~h}$, whereas its stabilities decreased significantly at pHs below pH 5.0 or above $\mathrm{pH} 11.5$ [14].

\section{Effects of metal ions and chemical agents on Opt-CGT activity}

To determine whether metal ions would affect the cyclization activity, the residual activity of metal-free enzyme was assayed by incubation with $1 \mathrm{mM}$ of divalent metal ions for $10 \mathrm{~min}$. As shown in Tables 3, $1 \mathrm{mM}$ of EDTA almost did not inhibit the enzymatic activity, indicating that the Opt-CGT represented a divalent metal ion non-dependent glycosyl transferase. $\mathrm{Zn}^{2+}, \mathrm{Co}^{2+}, \mathrm{Mn}^{2+}$ and $\mathrm{Mg}^{2+}$ ions had little effects on the activity, whereas $\mathrm{Fe}^{2+}$, $\mathrm{Cu}^{2+}$ and $\mathrm{Ni}^{2+}$ inhibited the activity at a final concentration of $1 \mathrm{mM}$. On the other hand, $1 \mathrm{mM}$ of $\mathrm{Ca}^{2+}$ or $\mathrm{Ba}^{2+}$ activated the cyclization activity of Opt-CGT up to 114.9 and $111.7 \%$, respectively. The effects of metal ions and the metal chelator on the recombinant Opt-CGT and non-optimized CGT were almost similar [14].

The effects of various chemical agents on the enzyme activity were also assessed (Table 3). Methanol, ethanol, acetonitrile, isopropanol, Tween 20, Tween 80 and SDS strongly inhibited Opt-CGT enzyme activity, whereas DMSO and Triton X-100 slightly reduced its activity. Urea had no significant influence on the enzyme activity. These data suggested that Opt-CGT was a metal ion non-dependent enzyme and its organic solvent tolerance is poor.

Overall, the biochemical characteristics are almost the same between Opt-CGT and native CGTase (Table 4). However, the half-life of the native enzyme at $50{ }^{\circ} \mathrm{C}$ is $48 \mathrm{~min}$, whereas the Opt-CGT was just about $20 \mathrm{~min}$, indicating that the native CGTase has a better thermal tolerance. Interestingly, there was some improvement in the $\mathrm{pH}$ stability of Opt-CGT, suggesting that the Opt-CGT still maintained an excellent stability at the $\mathrm{pH}$ 11.0.

\section{Production of AA-2G}

Many oligosaccharides and polysaccharides could be used as substrates for the transformation of AA-2G. Usually, $\alpha-C D$ was the ideal glycosyl donor for AA-2G production. The highest concentration of AA-2G reached $9.1 \mathrm{~g} / \mathrm{L}$ when the temperature, $\mathrm{pH}$, amount of enzyme, concentration of L-AA and $\alpha-C D$ were $40{ }^{\circ} \mathrm{C}$, 5.0, $60 \mathrm{U}, 100 \mathrm{~g} / \mathrm{L}$ and $100 \mathrm{~g} / \mathrm{L}$, respectively (Fig. 4). Jun et al. reported that $\mathrm{AA}-2 \mathrm{G}$ production concentration was $1.53 \mathrm{~g} / \mathrm{L}$ using $30 \mathrm{~g} / \mathrm{L}$ of AA, $70 \mathrm{~g} / \mathrm{L}$ of glycosyl donor and $2000 \mathrm{U} / \mathrm{mL}$ of CGTase in the catalytic system, which was much lower than this study [4].

In addition, due to the relatively high price of $\alpha-C D$, a lot of other glycosyl donors were selected, such as $\beta-C D$, soluble, corn and cassava starch. When $\beta$-cyclodextrin was used as the glycosyl donor, another cyclodextrin composed of seven glucose molecules, $4.9 \mathrm{~g} / \mathrm{L}$ of AA-2G could be obtained, and the decreased production maybe because the lower solubility of $\beta$-cyclodextrin. However, the cost of $\beta$-cyclodextrin is still expensive for industrial production. To further decrease the cost, starches were thought to act as the glycosyl donors, and the production of AA-2G reached $3.5,1.3$ and $1.5 \mathrm{~g} / \mathrm{L}$ from soluble, corn and cassava starch, respectively. Compared to the price of different starches, corn and cassava starch are more economic than soluble starch. However, when different starches were used as the glycosyl donors, the production of AA-2G was still at a relatively low level. Hence, future study should be performed to improve the AA-2G production from economic glycosyl donor.

\section{Conclusions}

The $\alpha$-CGTase encoding gene from $P$. macerans JFB05-01 was successfully codon-optimized and expressed intracellularly in E. coli BL21 (DE3) . The effects of N-terminal amino acids on activity of CGTase were also confirmed by truncation experiment. Then the recombinant enzyme was purified with a $55 \%$ yield by $\mathrm{Ni}^{2+}-\mathrm{NTA}$ resin and characterized its biochemical properties. In order to improve the production of AA-2G, the catalytic conditions are optimized based on the characterizations of purified Opt-CGT. In addition, considering the relatively high cost of cyclodextrin, the glycosyl donor could be changed to starches, but the production should be further improved.

\section{Funding}

This work was supported by the National Natural Science Foundation of China (Nos. 31700092, 21706125, 21727818, 21706124), the Postgraduate Research \& Practice Innovation Program of Jiangsu Province (KYCX18_1109), the Jiangsu Province Natural Science Foundation for Youths (Nos. BK20170993, BK20170997), the Jiangsu Synergetic Innovation Center for Advanced Bio-Manufacture (XTE1834), Project of State Key Laboratory of MaterialsOriented Chemical Engineering (KL17-09).

\section{Availability of data and materials}

The datasets supporting the conclusions of this article are included within the article.

\section{Authors' contributions \\ JM and DWL designed the experiments; JYJ, ZJ, WRF, XFX and ZWM performed the experiments; FY, MJF, ZJ, WRF and DWL analyzed the data; $J Y J$ and DWL wrote the paper; JM revised the paper. All authors read and approved the final manuscript.}

Ethics approval and consent to participate

Not applicable

Consent for publication

Not applicable

Competing interests

The authors declare that they have no competing interests. 


\section{Publisher's Note}

Springer Nature remains neutral with regard to jurisdictional claims in published maps and institutional affiliations.

\section{Author details}

'State Key Laboratory of Materials-Oriented Chemical Engineering, College of Biotechnology and Pharmaceutical Engineering, Nanjing Tech University, Puzhu South Road 30\#, Nanjing 211800, People's Republic of China. ${ }^{2}$ Jiangsu National Synergetic Innovation Center for Advanced Materials (SICAM), Nanjing Tech University, Nanjing 211800, People's Republic of China.

\section{Received: 24 April 2018 Accepted: 22 August 2018}

\section{Published online: 31 August 2018}

\section{References}

1. Jacob RA, Sotoudeh G. Vitamin C function and status in chronic disease Nutr Clin Care. 2010;5(2):66-74

2. Yamamoto I, Tai A. The current state on development of novel vitamin derivatives. Nihon Rinsho. 1999;57(10):2332-8.

3. Han R, Liu L, Li J, Du G, Chen J. Functions, applications and production of 2-OD-glucopyranosyl-L-ascorbic acid. Appl Microbiol Biotechnol. 2012;95(2):313-20.

4. Jun HK, Bae KM, Kim SK. Production of 2-O-a-D-glucopyranosyl L-ascorbic acid using cyclodextrin glucanotransferase from Paenibacillus sp. Biotechnol Lett. 2001;23(21):1793-7.

5. Tanaka M, Muto N, Yamamoto I. Characterization of Bacillus stearothermophilus cyclodextrin glucanotransferase in ascorbic acid 2-O-a-glucoside formation. Biochim Biophys Acta. 1991;1078(2):127-32.

6. Zhang Z, Li J, Liu L, Sun J, Hua Z, Du G, Chen J. Enzymatic transformation of 2-O-a-D-glucopyranosyl-L-ascorbic acid by a-cyclodextrin glucanotransferase from recombinant Escherichia coli. Biotechnol Bioprocess Eng. 2011;16(1):107-13.

7. Ng HS, Ooi CW, Mokhtar MN, Show PL, Ariff A, Tan JS, Ng EP, Ling TC. Extractive bioconversion of cyclodextrins by Bacillus cereus cyclodextrin glycosyltransferase in aqueous two-phase system. Bioresour Technol. 2013;142:723-6.

8. Fujiwara S, Kakihara H, Woo KB, Lejeune A, Kanemoto M, Sakaguchi K, Imanaka T. Cyclization characteristics of cyclodextrin glucanotransferase are conferred by the $\mathrm{NH}$-terminal region of the enzyme. Appl Environ Microbiol. 1992;58(12):4016-25.

9. Rather MY, Ara KZG, Nordberg Karlsson E, Adlercreutz P. Characterization of cyclodextrin glycosyltransferases (CGTases) and their application for synthesis of alkyl glycosides with oligomeric head group. Process Biochem. 2015:50(5):722-8.

10. Ong RM, Goh KM, Mahadi NM, Hassan O, Rahman RN, Illias RM. Cloning, extracellular expression and characterization of a predominant beta-CGTase from Bacillus sp. G1 in E. coli. J Ind Microbiol Biotechnol. 2008;35(12):1705-14.

11. Fenelon VC, Aguiar MF, Miyoshi JH, Martinez CO, Matioli G. Ultrafiltration system for cyclodextrin production in repetitive batches by CGTase from Bacillus firmus strain 37. Bioprocess Biosyst Eng. 2015:38(7):1291-301.

12. Mathew S, Adlercreutz P. Cyclodextrin glucanotransferase (CGTase) catalyzed synthesis of dodecyl glucooligosides by transglycosylation using a-cyclodextrin or starch. Carbohydr Polym. 2012;87(1):574-80.

13. Yong J, Jin NC, Park SS, Park CS, Park KH, Yang DC. Secretion of heterologous cyclodextrin glycosyltransferase of Bacillus sp. E1 from Escherichia coli. Biotechnol Lett. 1996;18(10):1223-8.

14. Li Z, Li B, Gu Z, Du G, Wu J, Chen J. Extracellular expression and biochemical characterization of alpha-cyclodextrin glycosyltransferase from Paenibacillus macerans. Carbohydr Res. 2010;345(7):886-92.

15. Kim SG, Kweon DH, Lee DH, Park YC, Seo JH. Coexpression of folding accessory proteins for production of active cyclodextrin glycosyltransferase of Bacillus macerans in recombinant Escherichia coli. Protein Expr Purif. 2005; 41(2):426-32.

16. Park S, Chang KS, Jin E, Pack SP, Lee J. Oxaloacetate and malate production in engineered Escherichia coli by expression of codonoptimized phosphoenolpyruvate carboxylase2 gene from Dunaliella salina. Bioprocess Biosyst Eng. 2013;36(1):127-31.

17. Gruber AR, Lorenz R, Bernhart SH, Neubock R, Hofacker IL. The Vienna RNA websuite. Nucleic Acids Res. 2008;36(Web Server):W70-4.

18. Amaral FE, Parker D, Randis TM, Kulkarni R, Prince AS, Shirasu-Hiza MM, Ratner AJ. Rational manipulation of mRNA folding free energy allows rheostat control of pneumolysin production by Streptococcus pneumoniae. PLoS One. 2015;10(3):e0119823.
19. Janknecht R, Martynoff G, Lou J, Hipskind RA, Nordheim A, Stunnenberg HG. Rapid and efficient purification of native histidine-tagged protein expressed by recombinant vaccinia virus. Proc Natl Acad Sci U S A. 1991;88(20):8972-6.

20. Laemmli UK. Cleavage of structural proteins during the assembly of the head of bacteriophage T4. Nature. 1970;227(5259):680-5.

21. Li G, Jiang Y, Fan XJ, Liu YH. Molecular cloning and characterization of a novel beta-glucosidase with high hydrolyzing ability for soybean isoflavone glycosides and glucose-tolerance from soil metagenomic library. Bioresour Technol. 2012;123:15-22.

22. Sinha R, Khare SK. Characterization of detergent compatible protease of a halophilic Bacillus sp. EMB9: differential role of metal ions in stability and activity. Bioresour Technol. 2013;145:357-61.

23. Dong $W$, Jiang S, Shi K, Wang F, Li S, Zhou J, Huang F, Wang Y, Zheng Y, Hou Y, Huang Y, Cui Z. Biodegradation of fenoxaprop-P-ethyl (FE) by Acinetobacter sp. strain DL-2 and cloning of FE hydrolase gene afeH. Bioresour Technol. 2015;186:114-21.

24. Abdel-Naby MA. Immobilization of Paenibacillus macerans NRRL B-3186 cyclodextrin glucosyltransferase and properties of the immobilized enzyme. Process Biochem. 1999;34(4):399-405.

25. Tuller T, Waldman YY, Kupiec M, Ruppin E. Translation efficiency is determined by both codon bias and folding energy. Proc Natl Acad Sci U S A. 2010;107(8): 3645-50.

26. Darabi P, Galehdari H, Khatami SR, Shahbazian N, Shafeei M, Jalali A, Khodadadi A. Codon optimization, cloning and expression of the human leukemia inhibitory factor (hLIF) in E. Iran J Biotechnol. 2013;11(1):47-53.

27. Yin J, Bao L, Tian H, Gao X, Yao W. Quantitative relationship between the mRNA secondary structure of translational initiation region and the expression level of heterologous protein in Escherichia coli. J Ind Microbiol Biotechnol. 2016;43(1):97-102.

28. Su N, Wu JJ, Li Y, Zhang C, Li M, Xing XH. Construction of MBP fusion heparinaselll efficient expression system in E.coil. CIESC J. 2014;65(7):14.

29. Liu H, Li J, Du G, Zhou J, Chen J. Enhanced production of alpha-cyclodextrin glycosyltransferase in Escherichia coli by systematic codon usage optimization. J Ind Microbiol Biotechnol. 2012;39(12):1841-9.

30. Bian F, Yue S, Peng Z, Zhang X, Chen G, Yu J, Xuan N, Bi Y. A comprehensive alanine-scanning mutagenesis study reveals roles for salt bridges in the structure and activity of Pseudomonas aeruginosa elastase. PLoS One. 2015; 10(3):e0121108.

31. Han R, Li J, Shin HD, Chen RR, Du G, Liu L, Chen J. Recent advances in discovery, heterologous expression, and molecular engineering of cyclodextrin glycosyltransferase for versatile applications. Biotechnol Adv. 2014;32(2):415-28.

32. Veen BA, van Alebeek GJ, Uitdehaag JC, Dijkstra BW, Dijkhuizen L. The three transglycosylation reactions catalyzed by cyclodextrin glycosyltransferase from Bacillus circulans (strain 251) proceed via different kinetic mechanisms. Eur J Biochem. 2000;267(3):658-65.

Ready to submit your research? Choose BMC and benefit from

- fast, convenient online submission

- thorough peer review by experienced researchers in your field

- rapid publication on acceptance

- support for research data, including large and complex data types

- gold Open Access which fosters wider collaboration and increased citations

- maximum visibility for your research: over $100 \mathrm{M}$ website views per year

At $\mathrm{BMC}$, research is always in progress.

Learn more biomedcentral.com/submissions 